\title{
WHAT IS EVENT-LED REGENERATION? ARE WE CONFUSING TERMINOLOGY OR WILL LONDON 2012 BE THE FIRST GAMES TO TRULY BENEFIT THE LOCAL EXISTING POPULATION?
}

\author{
DEBORAH (DEBBIE) SADD
}

School of Services Management, Bournemouth University, Poole, UK

\begin{abstract}
When London won the bid to host the Games, the vision was underpinned by key themes, one of which was to leave a legacy of benefiting the community through regeneration. The regeneration of the Lower Lea Valley was promised to be for the direct benefit of everyone who lives and works there, involving significant social and economic advancement. However, Mace, Hall, and Gallent draw parallels through the previous urban regeneration projects in major cities and they argue that for regeneration to work it has to be for the benefit of the existing communities and not "new" communities who inhabit the area post the Games. Could this happen in East London and, despite Government plans, the developments lead to an extension of the Docklands renaissance, inhabited instead by mostly middle class workers? This article explores the difference between regeneration and gentrification in the context of London 2012 and other Olympic Games. Much of the published literature regarding London's legacy of urban regeneration has a positive slant, yet, through the analysis of documentation from previous Games and through in-depth interviews with key stakeholders, the research highlights a number of issues that London 2012 will need to address.
\end{abstract}

Key words: Regeneration; Event legacies; London 2012; Gentrification; Community as "stakeholder"

Introduction

The background to this research has arisen out of the winning of the bid in 2005 of London to host the Games of 2012. The article looks at whether the hosting of the event will lead to the desired regeneration of the Lower Lea Valley area or whether it will become a gentrified area, as seen before with the hosting of the Olympic Games in other major cities around the world.
In particular, the research will focus on exactly what is legacy, whether it is a global definition, whether better descriptors apply. It will then focus on the sociocultural legacies seen from previous Games with lessons to be learned from these case studies for London, culminating in suggesting the correct descriptors to use for London and the anticipated social impacts the hosting will create in relation to the local communities.

The research undertaken was key informant in- 
terviews, through purposive sampling, of individuals who were involved in or affected by previous Olympic Games in Barcelona and Sydney. Further interviews were also undertaken with key individuals from the planning of London 2012. The interview data were then analyzed thematically.

The results emerging highlight several issues that London should consider if it wishes to avoid the area in the Lower Lea Valley become gentrified, thus replacing the existing community with higher social classes as seen in both Barcelona and Sydney.

\section{Olympic Event Legacy}

Events have long been associated with being a catalyst for urban change (Chalkley \& Essex, 1999), but without clearly articulating what change occurs and for whom, thus paving the way for gentrification; upgrading the social environment for receiving new residents. In consequence, the question arises as to whether events need regeneration projects to adopt or do regeneration projects need events.

However, it is important to discuss exactly what is meant by event legacy in Olympic terms. The use of this word has even been discussed at an International Olympic Committee Symposium in 2002 in Lausanne, where the translation of the word highlighted its inconsistencies in many different languages; for instance in France it means heritage, which has another meaning altogether; in Spanish, hereditary inheritance. The symposium did not offer alternatives; however, the use of impacts and benefits is becoming more widely accepted as alternative descriptors, especially with a global audience and for this article impacts will be interchangeable with legacy (International Olympic Committee [IOC], 2002). However, traditionally legacy denotes something that "kicks in" as a result of something related happening, as it is preplanned to happen at a certain time in the future. Volrath (2005) argues that legacy is the aims, motives, meanings, and impacts of the Olympic Games yet more specifically the results, effects, and long-term implications. This view is now evolving that legacy is a phenomenon relating to before, during, and after something else happening. Ritchie (2000) believes that legacy planning in respect of the Olympics can lead to the attainment of long-term benefits to host destination residents. The city transformations that can be undertaken as a result of hosting mega-events depend on the quality of the planning and this will therefore include any housing issues. For a sustainable legacy, all the objectives of the various stakeholders need to be addressed and a holistic approach taken to the development and management of the Olympic facilities. The regeneration dividend should become a blueprint for future Olympic cities.

To set the context of London and its hosting of the 2012 Games, many cities use the Olympics as a way of increasing tourism receipts, destination awareness, and brand recognition, but none of these apply to London as it is a major global tourist destination. However, what is pertinent is the setting for the Olympic Park being based in east London, which is a socially deprived area and therefore the social legacy plans place a huge onus on the organizers and central government to use the Games as a route to regenerate a very poor and underdeveloped part of London. Indeed, the former Mayor of London, Ken Livingstone, hoped the hosting of the Games would encourage businesses to relocate there and draw the investors out of central London and the traditional enclave of The City, much as Canary Wharf has encouraged much relocation from the City of London financial area. As already mentioned in this article, the term legacy and impacts are interchangeable.

Event social legacy impacts have a long-term implication where they have been successful in previous Games, that is to say Barcelona; they have been part of a longer term vision that continues well after the Olympics are over. In Sydney's case the exact opposite was true, as everything seemed to end on the final day of the Paralympics Games, with no legacy planning being undertaken post-Games in the immediate period (Cashman, 2006). This especially manifested itself within the feasibility planning of the stadia in Sydney Olympic Park. So much can be learned from these experiences for the London team and in particular for the London residents adjacent to the development site in the Lower Lea Valley. The bid from the London team was focused almost entirely not on London as a destination, but about the legacy developments that the London team planned not only 
with regard to sports participation and sport development globally but also on the opportunity to improve the lives of the residents within the five London boroughs who would be acting as hosts. It is interesting that no previous Olympic bid ever promoted legacy, in particular social legacy, so emphatically.

Hall (1992) quotes "the impact of an Olympic Games on a host city is immense and profound and requires huge commitment by Governments, business and the community. The sporting programme of Games lasts only 16 days, yet their successful staging is the result of years of dedication and hard work by literally thousands of people" (p. 36). However, even he has not recognized the post-Games period within this quote, nor the opportunities for regeneration, again referring back to Sydney 2000 and the lack of legacy planning resulting in many "white elephants," where two of its stadia have gone into administration in the past (Searle, 2002). No single Games have ever planned its legacy beforehand in the manner of the London bid.

The use of events can be exploited to redevelop urban areas through the new infrastructure required and that the expenses incurred are offset against the improvements to airports, sewage and housing, especially in inner city areas. This is often quoted as a strong motive for bidding for the Olympic Games. Hu and Ritchie (1993) and Chalkley and Essex $(1999,2000)$ also believe large-scale events have the potential for being a catalyst for redevelopment, imaging, and place promotion. Smith and Fox (2007) argue that large events have long been associated with the physical regeneration of cities because of the opportunities to capitalize on the softer social and economic regeneration. They write in particular about Barcelona and how three events have shaped the city of today: the 1888 World's fair, 1929 World Exposition, and 1992 Olympic Games. In the case of Manchester and the 2002 Commonwealth Games there involved initiatives, on a small scale, that were designed to deliver softer initiatives that were not wholly reliant on the games themselves.

\section{Impacts on communities}

"The task ahead for London is to embed the preparation for the hosting of the Games into a broader social policy agenda from the outset. Delivering social legacies are people based issues not facilities." (London 2012 Candidate File, 2005, p. xi)

Research on the social legacy impacts of events, although limited, is becoming increasingly important (Cashman, 2006; Fredline, Jago, \& Deery, 2003; Waitt, 2001). Although such impacts are difficult to quantify, they are often examined through the residents' perceptions of the impacts (Fredline et al., 2003). Such impacts include developing a sense of place and community pride in conjunction with quality of life (Ritchie, 2000; Cashman, 2006) and the enhancement of social capital, vital in maintaining a productive and lively society. It is often assumed that if the economic benefits of an event are positive it should therefore follow that the social impacts will also be positive. However, Malfas, Theodoraki, and Houlihan (2004) argue that while events may seen attractive through the positive economic benefits they accrue, the social impacts can be negative, particularly when residents are forced to leave their publicly funded housing projects to make way for event infrastructure. They highlight the case of the Atlanta 1996 Olympic Games when 9,500 units of affordable housing were lost and $\$ 350$ million in public funds diverted from lowincome housing and the social services to fund the Olympic preparation. However, given the past history of the Olympics it is questionable whether there are any true positive economic benefits to the organizers, with the exception of the 1984 Los Angeles Olympics, entirely run by private funding.

There are several writers that question the role of regeneration through events including Hall (1997) and Lenskyj (2002), who question the public expenditure required to host these events and if the benefits from these events actually accrue to the most needy and deserving. To overcome these objections, many cities are using events to kickstart specific regeneration initiatives. For an Olympic bid to be successful Cashman (2006) further argues that the host community and key interest groups must be involved, including any lobby groups, from the very beginning as the bid is prepared and that this consultation should continue even into the post-Games legacy period through recognizing the stakeholders involved. While the 
politics of the ruling government and also the politics of the organizing committee may see several changes of personnel, some continuity must exist in key personnel. A central figure is needed to control the power and in Sydney's case it was Michael Knight who became Minister for the Olympics. At present the UK equivalent is Tessa Jowell MP, the Olympics Minister, but what will happen to her role if there is to be a change of Government is at present unknown.

Atkinson and Laurier (1998) write about the 1996 Bristol International Festival of the Sea and the consequences of the event on urban areas and in particular how two groups of travelers were forced to relocate as the festival approached. The local council felt that the travelers would be an unsightly offense in terms of tourist gaze and not part of the new maritime heritage identity that Bristol wanted in relation to its place marketing. Interestingly, the heritage of Bristol's' past involvement in the slave trade was entirely ignored. In Atlanta for the 1996 Games, residents were forced to leave their publicly funded housing projects in order to make way for event infrastructure. In Barcelona, the developments necessitated the relocation of indigenous sea gypsies from the waterfront and in London's case the relocation of traveler communities is also being undertaken from the Games site. Barcelona used the Olympic planning to be focused on the long-term benefits of the city as a whole by having good transport links between the various sites and strategically planning for the whole of the city to benefit from the redevelopments.

In order to discuss the legacy impacts on the community it is necessary to evaluate who and what is the community. Just because people all live in the same area does not immediately confer on them the status of all belonging to the same community; likewise, a community does not always have to be just residents as communities of place arise through linkages and commonalities of place (i.e., allotment holders, ramblers, businesses, open space users, sporting clubs, etc.) as well as communities of association, interest, and attachment (Hargreaves, 2004; Stewart, 2006; Ziller, 2004). In addition, when Government documents talk about the community after the Games having more skilled workers, better education, better healthcare, and living conditions, they avoid confirming the community before and after the Games being the same people and the same social status. Past examples from Barcelona and Sydney both underwent gentrification around their previous Olympic villages spreading out to the surrounding areas as well.

Too often in the past social legacy has been as afterthought in the planning and execution of previous Games. In London the Games can generate opportunities for new investments in jobs and other soft infrastructure, while at the same time physically transforming the landscape. The importance of embedding a wide range of projects in the delivery of a sound social legacy can be the impetus to radically develop one of the most disadvantaged urban areas in Europe. This "model" could become an example of best practice that could have wide reaching benefits (Coalter, 2004).

Critics (Ball \& Greene, 1997; Lenskyj, 2002; Olds, 1998; Ritchie \& Hall, 1999) would argue that the benefits are not so straight forward, as these developments can increase social inequalities through greater than before costs of living and not necessarily improving the lifestyles of the most deprived members of the community, in some cases even moving them away from the area. Looking back into the archives of Barcelona, 1992, and interviewing people involved at the time and subsequently within the planning of what happened, the most important fact from Barcelona is the long-term vision that was taken to change the infrastructure of the city emerging from the postFranco era of dictatorship. The premise was to return the city to the population and develop more open spaces for the populous to use and to improve transport links. Another major focus of the "Grand Metropolitan Plan" was to open up the seafront again and encourage the residents to face the sea once more, as for years the coastline had been industrial and used as a port. The plans for the Olympics were split into four geographical areas for quite distinct reasons but all focused to develop former industrial and neglected areas for the existing citizens. However, post-Games the ex Olympic Village became inhabited by young professionals, many of whom had migrated to the city from within Europe, attracted by the technological businesses developing in the city. Many locals could no longer afford to live in this area, particu- 
larly with the attraction of the newly developed seafront caused a "ripple" effect on house prices back inland. A long-term project vision of 25 years was undertaken in 6 years, but after the Games the developments continued and are still ongoing today, yet the previous residents of the area have been forced to relocate to cheaper areas of the city exhibiting classic gentrification (interviews in 2007).

Development and change must consider those cultural and social values of place, in that businesses are often located in run-down areas for a reason, possibly due to lack of developer interest and low rents. As seen in the case of Barcelona, moving for the sake of change can have lasting negative social repercussions. In clearing the seafront area, many local businesses were evicted; however, they had significant social and cultural heritage in being positioned on the seafront in the first place, including the "sea gypsy" communities. There is often the danger that local community priorities get ignored as development partnerships become dominated by "movers and shakers," thus limiting the "bottom up" participation approach (Hiller, 1998; Waitt, 1999). This "bottom up" approach promotes socially sustainable regeneration and it becomes development in, rather than development of, the area.

Grantham (2006) believes that the key impacts will be seen in the run up to 2012. Stratford City will feel the real estate impacts the most as the surrounding area will be transformed with improved transport links, increases in office and retail, leisure, and social space as part of an ongoing project started before the bid was won in 2005 . He also believes that residential property prices in the area will show significant increases; Barcelona prices rose by $131 \%$ in the 5 years running up to 1992 , compared to $83 \%$ across Spain as a whole over the same period-post-Games (interview in 2007). This may have an impact on the local residents and on the prices of the properties post the Games, especially the key worker properties, part of the new 9,000 new homes planned for the Olympic zone, mentioned in the bid document. What will happen to the "poorer communities," how will they survive, will homelessness rise and unscrupulous landlords capitalize on the property rises to demand over inflation rent increases?
(Olds, 1998). This time for London the increases will be perhaps limited by the financial crisis.

However, what works well for one city doesn't automatically mean it will work well in every city. What was important about Barcelona's regeneration of the city was that the benefits accrued more to the locals than to tourists. The Olympic legacy for Barcelona resulted in the creation of projects in areas that would not normally seem immediately suitable. Coalter (2004) writes about the role of sport and the role of the Olympics in helping to build communities through sport. He reviewed evidence from previous mega-events including Veal (2003) and his work from the Sydney 2000 Games, which produced a mixed picture and argued that changes were difficult to attribute to the Olympics alone. Sport and social regeneration is more about participation and especially the role the voluntary sector can play in that. Sustainable regeneration is founded on local organizations working together. Mihalik and Simonetta (1999), implementing a trend survey of resident perceptions of the Atlanta Games, found that the residents ranked intangible benefits higher than the economic ones in terms of level of citizen support, although support diminished the closer the Games got as they became more concerned about the negative benefits. The lesson for future games is that is it imperative to garner, foster, and maintain community support, especially if they perceive they are not getting value for money out of the infrastructure improvements in comparison to the disbenefits.

\section{Community Stakeholder Identification}

In order for their voices to be heard and to be consulted on the developments, the residents need to be identified as stakeholders within the developments being undertaken. Freeman, Wicks, and Parmar (1984) quote a stakeholder to be anyone who is affected by the actions of the organization, thus enabling the residents closest to the Olympic park in London to be considered as stakeholders. Unfortunately, this stakeholder identification is too late for the residents of the former Clays Lane Peabody estate, the traveler communities from Waterden Road and Clays Lane, the students from the halls of residence in Clays Lane, the allotment 
holders, and the many businesses that already have had to relocate from the park (interviews undertaken in 2007/2008). They had very little consultation or negotiation with the authorities about their relocations (except the gypsies, who had considerable legal representation). If these groups had been allowed proper stakeholder status from the outset their joint negotiating position may have been stronger. The terminology used within the description of the urban remodeling is crucial for regard to how this remodeling affects the local community who must be considered as stakeholders with Freeman's definition. It must be "urban regeneration" for it to benefit the existing community, not necessarily the "local community," as this can change substantially in the post-Games period.

In Sydney, in 2000, the main positive legacy to come out of the Games was the volunteering legacy which has been copied all over the world subsequently for many mega-events. Even though the Games were considered the "games ever" by the IOC President at the time Juan Antonio Samaranch, the post-Games legacy planning was nonexistent. Only in 2007, some 7 years later, did the park planners develop plans to turn the former Olympic venue into a vibrant city as opposed to an area of underutilized stadia (interviews in 2007). A vibrant community is needed, not in just the former Olympic village, which like Barcelona is occupied by professional people. Indeed, this effect again rippled out into the city for a while as an article written during the run up to the Games by Beadnell (2000) commented that the only race at the time was the rent race. Landlords capitalized on the hosting of the Games to upgrade their properties and forced out tenants in favor of higher rentals.

Furthermore, in Sydney, the local council Auburn were encouraged to persuade their local businesses to upgrade their properties in preparation of the Olympic visitors passing through and many spent thousands of dollars on their properties and businesses (interviews in 2007). During the Games period they had virtually no visitors because the spectator transport system was directly linked to the park and therefore no one came through the local community. Only the Turkish wrestling team visited as they had relatives in town. The former Mayor, Pat Curtin, warned against this overexpec- tation of huge visitors as he had visited Atlanta, after the 1996 Games, where exactly the same scenario occurred and many shopkeepers were closing their businesses as they had spent so much money on upgrading their premises, but had not generated the income during Games time to cover their additional costs. Pat Curtin tried to warn the council but because he had recently lost the Mayoral title to Lee Lam his warnings were dismissed as those of a disgruntled former official, who had on many occasions taken the organizing committee to task and was therefore not the most popular figure within the administration, yet his dire warnings have proved to be true (interviews in 2007). In addition, in Sydney, although most Games reports describe the area used for the park as being derelict and wasteland, there were businesses that had been operating there, including an abattoir and in total the loss of ratable income amounted to over Aus $\$ 1$ million. This was income that the council no longer had to spend on other services for the community (Cashman, 2006).

The disruption from the building and construction, while inconvenient, should have a purpose and positive outcome for the population yet more importantly the legacy planning for the post games period and in particular the use of the Olympic facilities once the Games have finished must include local consultation. This is where the concept of stakeholder theory becomes invaluable. The "pure" stakeholder theory dates back to the 1980's writings of Freeman et al. (1984), yet many critics including Key (1999) and Lepineuz (2005) argue that this "pure" form of the theory fails to include as stakeholder society as a whole and in particular those communities around the "center of operations" whether the theory apples to business organizations or organizations such as those responsible for the 2012 Olympics, where a two-way equitable partnership will allow for a win-win scenario to develop.

\section{Methodology}

The research has an inductive theoretical perspective where the methodology takes thematic analysis, with the actual method undertaken being the in-depth key informant, semistructured interviews. Interviews allow the researcher to discover 
the inconsistencies, contradictions, and paradoxes that describe daily life and augment understanding of what has occurred, how it happened, and why. Furthermore, by using a qualitative method a degree of elasticity permits emerging data to be iteratively integrated within the analyses. The use of in-depth interviews is justified as they allow depth for an interpretive, flexible data collection through exhibiting and developing trust and rapport with the interviewees in a complex area. Purposive sampling as each individual interviewee is chosen for their role as "stakeholder" within the different Games. Huberman and Miles (2002) propose that the goal should always be to choose subjects that replicate or extend the theoretical underpinning in this case stakeholder theory. The technique of "snowballing" will also be used where each interview helps to gain introductions to further subjects (Flick, 2006).

\section{London Issues Arising}

In London, the hosting of the 2012 Games has given the authorities the opportunity to truly benefit the existing local communities. However, with the current global credit crisis, many genuine regeneration opportunities are being squandered through the insistence of the organizers to build vast stadium at the cost of legacy planning. Even the appointment of Tom Russell as legacy Tsar, the former head of the New East Manchester Regeneration Company (developed to develop East Manchester in line with the hosting of the 2002 Manchester Commonwealth Games), cannot prevent valuable initiatives being lost due to necessary budget "realignments." The focus at present is to get the various hard infrastructures in place in line with IOC requirements. In relation to the main Olympic stadium, Leyton Orient and West Ham football clubs have in the past expressed interest in taking over the stadium post-Games, but the sticking point is the insistence by the organizers of having a running track around the perimeter of the pitch, a feature not popular with football clubs as their spectators insist on close proximity to the pitch. A report in the Guardian in August, 2008 (Scott, 2008) quoted Boris Johnson, the London mayor, as saying that the legacy of the athletics track maybe revised bearing in mind the capac- ity issues of the stadium as Athletics would not be able to fill such a big arena and cutting an 80,000 seat arena down to 25,000 post-Games would justify more usage than just for athletics. In response, the International Association of Athletics Foundations (IAAF) have insisted that the London bid team promised to leave the track in situ postGames as part of the legacy for sport in London.

Interviews carried out with local site residents highlighted the loss of facilities, amenities, and open spaces and the lengths with which the Olympic Delivery authority are prepared to go in order to progress with their plans. These include preventing any site photography, even from neighboring properties privately owned that over look the site, because of a perceived security risk.

I take a few panoramic shots from our balcony, because we look over the site, and we have had a few letters saying that we would prefer you not to, you can take the photos but we would prefer you not to put them up on your site because it could be used by any organization for plotting against us.

Even the visitors who go on the daily bus tours around the park are searched for cameras and recording devises before being allowed entry.

Legacy promises made in relation to community facilities within the one arena post-Games have been withdrawn due to budget constraints and so the community hall that was demolished in Clays Lane will not now be replaced.

about a year ago the planning permission came through on their site and somebody in the square picked up that it was going to be a lot smaller than we were originally told it was going to be. Right in the beginning we were told in the road show part of the Olympics that the handball court would be left in situ after the Olympics and it could be used for anything to do with the community but there would be a hall just at the entrance that could be used as a community centre. In the rescaled plans it was just going to be the basic handball court with stadia around it and that was going to be smaller and no entrance hall. When one of the residents picked this up we then sent off an email to the ODA and we were told that the whole credit crunch and everything came into the sort of argument and we are just wondering if they knew this all along and just bamboozled us in the beginning. 
Doubts are being voiced about how much landscaping will occur for the Olympic Park because budgets for the main stadium are forever increasing. The shrubbery and vegetation pictured in all the digital images may become just green patches of grass as money becomes required in finishing off infrastructure elsewhere in the plans. However, the use of open spaces has been highlighted as a key component of developing a mixed community where true regeneration is allowed to take place.

It's very easy to talk about social integration and social coalition it is very difficult to get this kind of mix and it takes time and it depends on the very different and very subtle mechanisms like the image of the other and local traditions. Public spaces are a tool that we have and it is not very used in its potential they can have. ... It is very difficult to get mixed housing but it is exceptionally easy and cheaper to get mixed public space.

As in Sydney, the Olympic Delivery Authority (ODA) claim the area was polluted, underinvested, and derelict, yet many businesses, communities, and infrastructure have had to be relocated. One such business facing removal is the East London Bus Group, which at the time of writing has only just relocated its depot from Waterden Road on February 16, 2008, to make way for the Olympic Developments, nearly 4 years after the bid was won. Part of the delay was in finding suitable alternatives for the storage of the buses to service their respective routes as the relocation had to be carefully orchestrated (East London Bus Group, 2008).

While the ODA talks about a city the size of Exeter being constructed, this includes other plans that were already underway including the Thames Gateway project and the Stratford International project, both of which were being developed before 2005 when the bid was won. Some interviewees wonder whether the promise of all the additional housing post-Games is actually going to be the majority of housing already earmarked for development and it is this housing that will be for key workers and not the ex-athletes and officials accommodation.

Now that is complicated because they are dealing with Lend lease who are building the athletes' village as they own the land and they are devel- oping the whole of the Stratford city thing as loads of Stratford stuff gets passed off as part of the Olympics.

In times of financial crisis and also bearing in mind that private money has not been forthcoming to the developer Lend Lease from the banking system, it may be more prudent to sell all the accommodation in the park at market value to recoup some costs and then spend more money on improving the facilities for the communities in the outlying areas.

\begin{abstract}
That is the quickest and the easiest way to make it appear that you have benefited the people, by changing the poor people with wealthy people because immediately the life expectancy goes up, crime levels go down and all the rest of it, employment levels go up so you can present it as if you have improved everybody's lives whereas all you have done is change the people.
\end{abstract}

The hosting of the Olympics will not solve the underlying social problems, but they could leverage the vital regeneration from the investments needed to host the Games. Within the $£ 9$ billion budget, $£ 2$ billion is for the preparation of the site and facilities, $£ 2$ billion for the running of the Games, leaving the remaining $£ 5$ billion earmarked for the regeneration project showing the enormity of the project ahead and that for every $£ 1$ spent, 75p is for legacy (Duckworth, 2006). David Higgins, the Chief Executive of the Olympic Delivery Authority, has argued strongly that the ODA approach to regeneration must include a responsible approach to the regeneration of the Lower Lea Valley that goes further than the building of the Olympic facilities and to include longterm legacy planning, especially in calling for more coordination between the ODA and the governmental departments intending to invest in the area. The Olympics Minister, Mrs. Jowell, however, reiterated the importance of distinguishing between those commitments needed to satisfy the IOC in the building of the Olympic Park and those costs associated with the regeneration planning, the responsibility of the Department of Communities and Local Government, yet the interviews undertaken show that this is still a gray area with regard to regeneration. 


\section{Summary}

In postmodern terms, events are now viewed as not so much a celebration of industrial and technological progress but as cultural celebrations and as opportunities as catalysts for urban improvements. Monclus (2006) associated urban strategies with large-scale international events as having been the catalysts for the urban regeneration but that the architectural and planning culture is very specific to each city, and while many studies have looked at the urban layouts of various mega-events, the analysis of these events as catalysts of urban regeneration has not been the subject of any in-depth specific analysis across many events. While there have studies undertaken (Chalkley \& Essex, 1999, 2000; Fayos-Sola, 1998; Hiller, 1998; Hughes, 1993; Olds, 1998) on the social impacts of megaevents, there have been no comparative studies involving in-depth interviewing of key stakeholders, including "communities" affected by the hosting of the respective mega-events, thus exploring commonalities and focusing specifically on those communities most affected by the Games. These urban regeneration legacies are often very specific to the Games in question but initial research is finding common areas of impacts and highlighting the importance of "stakeholder" identification. This research has highlighted several negative previous Games legacy impacts that have not been written about widely, in particular how urban regeneration is used commonly instead of more accurately gentrification. These legacy impacts are forming a pattern that unless London takes the initiative now, will follow previous Games where the area of the Olympic Park and surrounding area will become revitalized for the benefit of only middle class communities as opposed to true regeneration for the existing working class and immigrant communities. The debate here is not on whether it is right to develop for the existing communities or for the benefit of middle class newcomers; it is a study of what happens and that often it might not be the original vision of the planners. The evidence seen in past examples is often that the original intention was to develop for the existing community but the middle classes have benefited more. The impact of the global credit crisis must not be used as a smoke screen for reducing legacy plans; perhaps plans need to be reviewed with legacy at the forefront of decisions rather than a supplement.

Possible suggestions for London legacy planners include the following:

- The importance of stakeholder identification from the outset to include community as stakeholder and thereby planning legacy developments to benefit the existing communities. A process to identify and plan for realistic legacies must involve all relevant stakeholders and include as much information as possible, including any potential "non-positive" legacies. Many of these initiatives should be put into place before the Games, as distinct from those following the Games, to ensure true regeneration.

- Rental and ratable income lost from businesses and communities relocated from within the park area, with no compensation forthcoming to the local councils. This has knock-on impacts for the remaining community, so compensation should be given to local government, otherwise other services suffer.

- The local business people, while told prior to the Games that they had much to gain from the close proximity of the event, should be pragmatic in relation to the expected influx of visitors based on previous examples.

- The facilities developed for the "community" within the park should be priced for the existing community to use post-Games and not developed for private ownership via clubs and societies.

- For true mixed communities to exist, the planners should encourage mixed use open spaces alongside any mixed housing allowing the regeneration of open spaces for all as opposed to gentrification.

- Regeneration policies are more successful when they form part of a longer term, more widely planned and focused redevelopment plan to which the hosting of the mega-event is but one aspect yet concentrating on social issues as a priority.

\section{References}

Atkinson, D., \& Laurier, A. (1998). Sanitised city? Social exclusion at Bristol's 1996 International Festival of the Sea. Geoforum, 29(20), 199-206. 
Ball, J., \& Greene, K. (1997, June 4). Failure of public housing project shows danger of moving too fast. Wall Street Journal, p. S2.

Beadnell, M. (2000). Sydney's homeless to be removed from Olympics. Retrieved July 11, 2006, from http:// www.wsws.org/articles/2000/feb2000/olymp-f03.shtml

Cashman, R. (2006). The bitter sweet awakening-The legacy of the Sydney 2000 Olympic Games. Sydney: Walla Walla Press.

Chalkley, B., \& Essex, S. (1999). Urban development through hosting international events: A history of the Olympic Games. Planning Perspectives, 14(4), 369394.

Chalkley, B., \& Essex, S. (2000). The Olympic Games: Catalyst for urban change. Retrieved December 27, 2003 from www.goeg.plym.ac.uk/groups/olympic_games. htm

Coalter, F. (2004). London 2012: A sustainable sporting legacy. In A. M. M. Vigor (Ed.), After the goldrush: A sustainable Olympics for London. London: ippr and Demos.

Duckworth, S. (2006, December). Key benefits and opportunities from London 2012. Keynote speech at Countdown to London 2012, How the Games Will Deliver for the Country. House of Commons, Westminster, London.

East London Bus Group. (2008). Farewell tours to Waterden Road. Retrieved March 4, 2009 from www.elbg. com/templateView.aspx?id=5648\&sec_id=2921

Fayos-Sola, E. (1998). The impact of mega-events. Annals of Tourism Research, 25, 241-245.

Fredline, L., Jago, L., \& Deery, M. (2003). The development of a generic scale to measure the social impacts of events. Event Management, 8, 23-37.

Flick, U. (2006). An introduction to qualitative research. London: Sage.

Freeman, R. E., Wicks, A. C., \& Parmar, B. (1984). Stakeholder theory and 'The corporate objective revisited'. Organizational Science, 15(3), 364-369.

Grantham, G. (2006). Capital gains? Locum Destination Review, 18, 28-30.

Hall, C. M. (1992). Hallmark tourist events: Impacts, management, and planning. London: Belhaven Press.

Hall, C. M. (1997). Mega-events and their legacies. In P. E. Murphy (Ed.), Quality management in urban tourism. Chichester: John Wiley.

Hargreaves, A. (2004). Building communities of place: Habitual movement around significant places. Journal of Housing and the Built Environment, 19, 49-65.

Hiller, H. (1998). Assessing the impact of mega-events: A linkage model. Current Issues in Tourism, 1, 47-57.

Hu, Y., \& Ritchie, J. R. B. (1993). Measuring destination attractiveness: A contextual approach. Journal of Travel Research, 32, p.25.

Huberman, A. M., \& Miles, M. B. (2002). The qualitative researchers companion. London: Sage

Hughes, H. L. (1993). Olympic tourism and urban regeneration. Festival Management \& Event Tourism, 1, 157162.
International Olympic Committee. (2002). Conclusions and recommendations. In International Symposium on Legacy of the Olympic Games, 1984-2000.

Key, S. (1999). Toward a new theory of the firm: A critique of stakeholder "theory." Management Decision, 37(4), 317-328.

Lenskyj, H. J. (2002). The best Olympics ever? Social impacts of Sydney 2000. New York: State University of New York Press.

Lepineuz, F. (2005). Stakeholder theory, society and social cohesion. Corporate Governance, 5(2), 99-110.

London 2012 Candidate File. (2005). Theme 1-Concept and legacy. London: London 2012.

Mace, A., Hall, P., \& Gallent, N. (2007). New East Manchester: Urban renaissance or urban opportunism? $\mathrm{Eu}$ ropean Planning Studies, 15, 51-65.

Malfas, M., Theodoraki, E. \& Houlihan, B. (2004). Impacts of the Olympic Games as mega-events. Municipal Engineer, 157(3), 209-220.

Mihalik, B. J., \& Simonetta, L. (1999). A midterm assessment of the host population's perceptions of the 1996 Summer Olympics: Support, attendance, benefits, and liabilities. Journal of Travel Research, 37(3), 244-248.

Monclus, F. J. (2006). International exhibitions and planning. Hosting large-scale events as place promotion and as catalysts of urban regeneration. In Culture, Urbanism and Planning. Aldershot, UK: Ashgate Publishing Limited

Olds, K. (1998). Urban mega-events, evictions and housing rights: The Canadian case. Current Issues in Tourism, 1(1), 2-46.

Olympic Delivery Authority. (2005). Key benefits and opportunities for London 2012. Paper presented at conference: Countdown to London 2012: How will the Games deliver for the country? Westminster, London.

Ritchie, J. R. B. (1987). The impacts of the 1988 Winter Olympics on Calgary: A tourism perspective. In 18th Annual Conference Travel and Tourism Research Association, Seattle, WA, USA.

Ritchie, J. R. B. (2000). Turning 16 days into 16 years through Olympic legacies. Event Management, 6, 155165.

Ritchie, B., \& Hall, C. M. (1999). Mega-events and human rights. Paper presented at conference: How to play the Game: The contribution of sport to the promotion of human rights. Human Rights Council of Australia, September 1-3, Sydney, Australia.

Scott, M. (2008). London 2012 stadium may not have athletics legacy after all. Retrieved February 23, 2009, from www.guardian.co.uk/uk/2008/aug/21/olympics2012. olympics2008/print

Searle, G. (2002). Uncertain legacy: Sydney's Olympic Stadiums. European Planning Studies, 10, 845-847.

Smith, A., \& Fox, T. (2007). From 'event-led' to 'eventthemed' regeneration: The 2002 Commonwealth Games Legacy Programme. Urban Studies, 44(5), 1125-1143.

Stewart, W. (2006). Community-based place meanings for park planning. Leisure/Loisir, 30(2) 405-416. 
Veal, A. J. (2003). Tracking change: Leisure participation and policy in Australia: 1985-2002. Annals of Leisure Research, 6(3), 246-278.

Volrath, A. (2005). Eternity games. In D. Adair, B. Coe, \& $\mathrm{N}$ Gouth (Eds.), Beyond the torch-Olympics and Australian culture. Melbourne: Australian Society for Sports History.

Waitt, G. (1999). Playing games with Sydney: Marketing
Sydney for the 2000 Olympics. Urban Studies, 36(7), 1055-1077.

Waitt, G. (2001). The Olympic spirit and civic boosterism: The Sydney 2000 Olympics. Tourism Geographies, 3(3), 249-278.

Ziller, A. (2004). The Community is not a place and why it matters: Case study. Green Square. Urban Policy and Research, 22(4), 465-479. 